\title{
Effect of the stirring speed on the struvite formation using the centrate from a WWTP
}

\section{Efecto de la velocidad de agitación en la formación de estruvita usando el centrado de una} PTAR

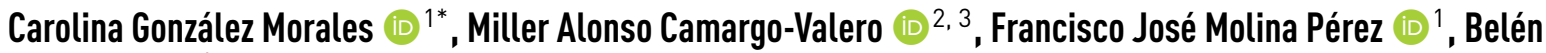 \\ Fernández $\mathbb{B}^{4}$ \\ ${ }^{1}$ Grupo GAIA, Escuela Ambiental, Facultad de Ingeniería, Universidad de Antioquia. Calle 70 \# 52-21. C. P. 050010. Medellín, Colombia. \\ ${ }^{2}$ BioResource Systems Research Group, School of Civil Engineering, University of Leeds. LS2 9JT. Leeds, UK. \\ ${ }^{3}$ Departamento de Ingeniería Química, Universidad Nacional de Colombia, Campus La Nubia. Km 9 vía al aeropuerto la Nubia. C. P. \\ 170003. Manizales, Colombia. \\ ${ }^{4}$ IRTA - Programa GIRO, Institut de ciència i Tecnologia Agroalimentàries, Torre Marimon, C. P. E08140. Caldes de Montbui, Barcelona, \\ Catalunya, Espanya.
}

\section{CITE THIS ARTICLE AS: \\ C. González, M. A Camargo, F. J. Molina, B. Fernández. \\ "Effect of the stirring speed on the struvite formation using the centrate from a WWTP", Revista Facultad de Ingeniería Universidad de Antioquia, 92, pp. 42-50, Jul-Sep 2019. [Online]. Available: https://www . doi.org/10.17533/ udea.redin. 20190518}

\section{ARTICLE INFO:}

Received: February 27, 2019

Accepted: May 21, 2019 Available online: May 21, 2019

\section{KEYWORDS:}

Waste water, phosphorus recovery, struvite crystallization, velocity gradient (g), sustainable development

Agua residual, recuperación de fósforo, cristalización de estruvita, gradiente de velocidad (g), desarrollo sostenible
ABSTRACT: The formation of struvite $\left(\mathrm{MgNH}_{4} \mathrm{PO}_{4} \cdot 6 \mathrm{H}_{2} \mathrm{O}\right)$ for nutrient recovery in wastewater treatment plants has been widely investigated; however, little attention has been paid to the effect of stirring speeds on the resulting particle size, which could affect its agronomic value as a slow-release fertilizer. In this study, struvite formation from the centrate of sewage digestate was performed under six stirring speeds $(0,100,200,300,400,500 \mathrm{rpm})$. The resulting struvite crystals were characterised using $X$-ray diffraction and scanning electron microscopy with energy dispersive $X$-ray spectroscopy. The average particle size of struvite crystals increased from $55 \mu \mathrm{m}$ at $0 \mathrm{rpm}$ to $127 \mu \mathrm{m}$ at $100 \mathrm{rpm}$ and $128 \mu \mathrm{m}$ at $200 \mathrm{rpm}$. Further increments in stirring speeds resulted in smaller crystal sizes. These results indicated that the largest particle size can be obtained at stirring speeds ranging from 100 to $200 \mathrm{rpm}$, equivalent to a velocity gradient between 79 and $188 \mathrm{~s}^{-1}$, as there was no statistically significant difference between mean values ( $t$-test, $p<0.05)$. The optimum stirring speed range reported herein can be used to set operational conditions for struvite crystallisation with the benefit of producing large crystals and reducing energy consumption in stirring tanks.

RESUMEN: La formación de estruvita $\left(\mathrm{MgNH}_{4} \mathrm{PO}_{4} \cdot 6 \mathrm{H}_{2} \mathrm{O}\right)$ para la recuperación de nutrientes en plantas de tratamiento de aguas residuales ha sido ampliamente investigada; sin embargo, se ha prestado poca atención al efecto de las velocidades de agitación en el tamaño de partícula resultante, lo que podría afectar su valor agronómico como fertilizante de liberación lenta. En este estudio, la formación de estruvita del centrado se realizó a seis velocidades de agitación (0, 100, 200, 300, 400, 500 rpm). Los cristales de estruvita resultantes se caracterizaron mediante difracción de rayos $X$ y microscopía electrónica de barrido con espectroscopia de rayos $\mathrm{X}$ con dispersión de energía. El tamaño de partícula promedio de los cristales de estruvita aumentó de $55 \mu \mathrm{m}$ a $0 \mathrm{rpm}$ a $127 \mu \mathrm{m}$ a $100 \mathrm{rpm}$ y $128 \mu \mathrm{m}$ a $200 \mathrm{rpm}$. Incrementos adicionales en las velocidades de agitación resultaron en tamaños de cristales más pequeños. Estos resultados indicaron que el mayor tamaño de partícula se puede obtener a velocidades de agitación entre 100-200 rpm, equivalente a un gradiente de velocidad entre 79 y $188 \mathrm{~s}^{-1}$, ya que no hubo diferencias estadísticamente significativas entre los valores medios (prueba $t, p<0.05$ ). El rango óptimo de velocidad de agitación descrito aquí se puede usar para establecer condiciones operativas para la cristalización de estruvita con el beneficio de producir cristales grandes y reducir el consumo de energía en tanques agitados.



\section{Introduction}

Phosphorus $(\mathrm{P})$ and nitrogen $(\mathrm{N})$ are the main nutrients causing eutrophication that lead to biodiversity loss and 
water quality problems [1, 2]. However, although an excess of phosphorus is problematic, modern agriculture is highly dependent on phosphorus fertilizer, which is derived from phosphate rock, a non-renewable resource with global reserves expected to be depleted within the following 50-100 years [3], making a strong problem for its contribution to agricultural and industrial development.

Both problems, phosphorus source depletion and eutrophication, can be tackled at the same time by the application of technologies aimed at recovering nutrients from wastewater streams [4]. For example, the centrate from anaerobic digesters in Wastewater Treatment Plants (WWTP), which is a $\mathrm{N}$ - and P-rich stream produced after sewage digestate dewatering, with concentrations between $750-1,500 \mathrm{mg} \mathrm{N} \mathrm{L}{ }^{-1}$ for nitrogen and 40-400 $\mathrm{mgP} \mathrm{L}^{-1}$ for phosphorus compounds. Those figures are typical from WWTP using enhanced biological nutrient removal (EBNR) processes [5-8], which represents a good opportunity to recover nutrients from domestic wastewater. A technique proven to be a successful method to recover phosphorus from phosphorus-rich streams is the precipitation of struvite $\left(\mathrm{MgNH}_{4} \mathrm{PO}_{4} \cdot 6 \mathrm{H}_{2} \mathrm{O}\right)$ [9]. Struvite is an effective, slow-release fertilizer that can be used to close the nutrient loop in between waste production and agriculture, as it simultaneously recovers $\mathrm{N}$ and $\mathrm{P}$ from waste effluents $[10,11]$.

Hence, struvite offers multiple benefits including limited negative impacts from agricultural runoffs into freshwater bodies, when compared with traditional chemical fertilizers. In fact, $\mathrm{N}$ losses have been reported to be considerably lower in struvite-treated soils than in soils receiving chemical fertilizers [10]. Struvite can also reduce nitrous oxide emissions and the need for phosphate rock, thus creating a more sustainable environment in line with a wider circular economy approach.

To date, various kinds of reactors have been developed at laboratory, pilot and full scales showing a great potential in recovering struvite from waste streams, among them are: fluidized bed reactor (FBR), air lift reactor and continuously stirred tank reactor (CSTR) $[12,13]$. FBR is the most commonly used due to its ability to produce struvite pellets of large size, high crushing strength and purity [14]; however, its operation requires high flow rate and energy for mixing to ensure that the bed is continuously fluidized, so different efforts have been made to reduce energy demand and minimize losses of fine particles remaining in solution [15]. Guadie et al. [1] used a novel cone-inserted fluidized bed reactor for reduce unwanted crystal loss, while Le Corre [16] used stainless steel meshes to reduce the loses of fine particles in the effluent; Wang [17] conducted an economic analysis in FBR reactor using different $\mathrm{Mg}$ sources. On the other hand, in air-lift reactors air increases the $\mathrm{pH}$ by $\mathrm{CO}_{2}$ stripping and creates an internal recycle flow that allows crystals to grow until a critical particle size [18], however the costs of energy used in aeration can be considerably high. The stirred reactor or CSTR is one of the simplest and most effective technologies to produce struvite [19, 20], although the mixing force and the reactor hydrodynamics are significant factors that contribute to the formation of struvite crystals [21, 22].

In a stirred reactor, hydraulic shear forces can break struvite crystals into smaller fractions, which ultimately affect the resulting size of the precipitates [21]. These fine precipitates are more likely to be washed out with the effluent, decreasing the recovery of precipitates. Therefore, in order to optimize P-recovery efficiency after crystallization, it is beneficial to aim for larger particle sizes [20]. Additionally, larger struvite particles will have a longer effect on soils, increasing the absorption of nutrients from plants and crops [18].

The effect of stirring speed on struvite formation and on particle size has been little investigated. Liu [23] showed that mixing rates and contact time increase phosphorus removal efficiency, while Cerrillo [24] found that the maximum particle size decreased when the mixing speed was increased from 100 to $200 \mathrm{rpm}$. These results agree with the work reported by Kim [25] indicating that in struvite precipitation processes, removal patterns of nitrogen and phosphorus from the solution increased logarithmically as a response to the increment of $G t_{d}$ values - i.e., the product between mixing intensity/velocity gradient $(G)$ and mixing duration $\left(t_{d}\right)$; however, the individual effect of $G$ on particle size at speeds between 0 and $500 \mathrm{rpm}$ is yet unknown. Therefore, it is important to evaluate the effect of stirring speed and mixing intensity in a wide range of velocity gradients $(G)$ in order to optimize the amount of energy needed in these reactors to obtain high percentages of $P$ and $N$ recovery and larger particles sizes of struvite precipitates.

Thus, the main objective of this study was to evaluate the effect of stirring speed on struvite precipitation using the centrate from a conventional municipal WWTP. The removal of nutrients and the particle size were assessed to obtain the optimum stirring range for a struvite mixing reactor.

\section{Materials and methods}

\subsection{WWTP}

Centrate samples were collected in the municipal WWTP of La Llagosta, located in the Catalonia autonomous community, province of Barcelona, Spain, at $41^{\circ} 30^{\prime} 12.62$ 




Figure 1 Localization of La Llagosta WWTP (Spain)



Figure 2 La Llagosta WWTP (Barcelona, Spain)

"N and $2^{\circ} 12^{\prime} 5.12^{\prime \prime} \mathrm{E}$ (Figure 1), which has a treatment capacity of $43,000 \mathrm{~m}^{3} \mathrm{~d}^{-1}$ and a population equivalent (p.e) of 358,000 inhabitants. This WWTP has a conventional system for the treatment of a blend of domestic and industrial wastewaters, which comprises pretreatment, primary settlement, and activated sludge units followed by a final secondary settling with chemical precipitation (Figure 2). The process can remove $56 \%$ TKN and $86 \%$ TP for the raw municipal wastewater.

\subsection{Analytical methods}

Centrate samples were analyzed at IRTA facilities (Caldes de Montbui, Spain). Cations $\left(\mathrm{Ca}^{2+}, \mathrm{Mg}^{2+}, \mathrm{K}^{+}\right)$and anions $\left(\mathrm{P}_{-} \mathrm{PO}_{4}{ }^{3-}\right)$ concentrations were analyzed by ionic chromatography using a Metrohm 790 IC equipped with a
Metrosep C4 150/4.0 column and a Metrohm 861 Advanced Compact IC equipped with a Metrosep A Supp 5-250 column and an $853 \mathrm{CO}_{2}$ suppressor, respectively. Total solids (TS), total suspended solids (TSS), volatile solids (VS), $\mathrm{NH}_{4}{ }^{+}-\mathrm{N}, \mathrm{TKN}, \mathrm{TP}$ and total alkalinity concentrations were determined according to Standard Methods [26]. The appearance of the precipitates was analyzed by using a scanning electron microscope (SEM, ZEISS EVOßMA 10) coupled to an energy dispersive $X$-ray microanalysis detector (EDX-Oxford, Inca) at Autonomous University of Barcelona (Cerdanyola, Spain). Meanwhile, the crystalline nature of precipitates was determined by X-ray diffraction (XRD, X'Pert Powder of Panalytical), using CuK-alpha radiation. The XRD patterns were recorded in the scanning range of 2 -theta from $10^{\circ}$ to $60^{\circ}$. Data were collected and processed using High-score-plus software. Identification 
of the phase peaks was accomplished by comparing the observed XRD patterns with a standard of struvite compiled by the the International Center for Diffraction Data (ICDD), the crystallography open database and the Powder Diffraction File (PDF) [27]. Crystal sizes were measured using Image J (1.51 J8) software [28] by making 120 measurements of the crystals length for each sample.

\subsection{Materials}

Due to the characteristics of the centrate, $\mathrm{MgCl}_{2} \cdot 6 \mathrm{H}_{2} \mathrm{O}$ and $\mathrm{NaH}_{2} \mathrm{PO}_{4}$ were added to balance the $\mathrm{P}: \mathrm{N}: \mathrm{Mg}$ molar ratio to $1: 6: 1.7\left(\mathrm{P}=300 \mathrm{mgP}-\mathrm{PO}_{4}{ }^{3-} / \mathrm{L}\right)$. This molar relationship was chosen because higher N:P molar ratio improves the precipitation of struvite instead of amorphous calcium and magnesium phosphates [29, 30], while $\mathrm{Mg}$ : Ca higher than 2:1 have the same effect [31]. Although struvite can precipitate at a wide range of $\mathrm{pH}$ values (7.0-11.5) [32], many investigations agree that the optimum $\mathrm{pH}$ value is around $9[24,33]$, for that reason $\mathrm{NaOH}$ in solution was added to reach $\mathrm{pH}$ 9. The principal conditions of the experiments are listed in Table 1.

\subsection{Experimental setup}

A standard jar tester with six paddles was used for struvite precipitation. Jars consist of $1 \mathrm{~L}$ cylindrical glass vessels with $130 \mathrm{~mm}$ internal diameter. The flat paddles at the end of each stirrer shaft, which were made of stainless steel with a length of $7.6 \mathrm{~cm}$ and a height of $2.5 \mathrm{~cm}$. The stirring device included a tachometer and a rev controller to adjust mixing rates ranging from 0 to $300 \mathrm{rpm}$. For the testing of mixing rates higher than $300 \mathrm{rpm}$, the same paddles were coupled to a laboratory stirrer. Mixing intensity $(G)$ values tested in this study varied from 0 to $591 \mathrm{~s}^{-1}$. The applied $G$ value was calculated based on the interaction between mixing rates of flat paddles and the corresponding velocity gradient based on a work previously reported [34] ,which found that the velocity gradient has a linear correlation to the impeller speed.

The applied mixing duration $\left(t_{d}\right)$ was 3 hours in the six-stirring speeds tested $10,100,200,300,400$ and 500 rpm) followed by 16 hours without stirring (Figure 3). After 16 hours without stirring, the solutions were filtered using $1.2 \mu \mathrm{m}$ membrane filters. In order to avoid struvite thermal decomposition that occurs above $55^{\circ} \mathrm{C}$ [35], the precipitates were air-dried at ambient temperature for 24 hours. Filters were weighed with and without the precipitate to calculate net struvite production; the TSS concentration from the centrate was also considered in order to calculate the total mass of struvite.

Considering that phosphate is the limiting reagent in this reaction, the maximum amount expected of struvite
Table 1 Test conditions

\begin{tabular}{|c|c|}
\hline Parameter & Values \\
\hline $\mathrm{pH}$ & 9 \\
\hline Temperature $\left({ }^{\circ} \mathrm{C}\right)$ & 12 \\
\hline Duration (h) & 3 \\
\hline Volume (L) & 1 \\
\hline Reagents used & $\begin{array}{l}\mathrm{MgCl}_{2} \cdot 6 \mathrm{H}_{2} \mathrm{O} \text { and } \\
\mathrm{NaH}_{2} \mathrm{PO}_{4}\end{array}$ \\
\hline $\mathrm{mg} \mathrm{P}_{-} \mathrm{PO}_{4}{ }^{3-} \mathrm{L}^{-1}$ & 300 \\
\hline $\mathrm{mg} \mathrm{Mg} \mathrm{Mg}^{2+} \mathrm{L}^{-1}$ & 389 \\
\hline $\mathrm{mg} \mathrm{N}-\mathrm{NH}_{4}{ }^{+} \mathrm{L}^{-1}$ & 825 \\
\hline $\mathrm{mg} \mathrm{Ca}^{2+} \mathrm{L}^{-1}$ & 261 \\
\hline \multicolumn{2}{|l|}{ Molar ratios } \\
\hline $\mathrm{N}-\mathrm{NH}_{4}{ }^{+} / \mathrm{P}-\mathrm{PO}_{4}{ }^{3-}$ & 6.1 \\
\hline $\mathrm{Mg}^{2+} / \mathrm{P}-\mathrm{PO}_{4}{ }^{3-}$ & 1.7 \\
\hline $\mathrm{Mg}^{2+} / \mathrm{Ca}^{2+}$ & 2.5 \\
\hline Stirred speed (rpm) & $0,100,200,300,400,500$ \\
\hline Replicates & 2 \\
\hline
\end{tabular}

was calculated by multiplying the mmols of phosphate present in the centrate by the molecular weight of struvite.

\section{Results and discussion}

The characterization of centrate samples reported the following mean values: $\mathrm{pH}=8.3$; reactive phosphorus $=1$ mgP-PO ${ }_{4}^{3-} \mathrm{L}^{-1}$; ammonium $=825 \mathrm{mgN}^{-\mathrm{NH}_{4}}{ }^{+} \mathrm{L}^{-1}$; calcium $=261 \mathrm{mgCa}^{+2} \mathrm{~L}^{-1}$; total suspended solids $=116 \mathrm{mg}$ TSS $\mathrm{L}^{-1}$; and total alkalinity $=3.1 \mathrm{gCaCO}_{3} \mathrm{~L}^{-1}$.

Struvite was obtained even under no stirring conditions, but the total amount recovered increased with the increment in stirring rates. Higher removal of $\mathrm{NH}_{4}{ }^{+}$was found as a result of increasing stirring speeds (Figure 4 and Table 2), which could be due to $\mathrm{NH}_{3}$ volatilisation. This did not affect struvite formation since the recovered struvite precipitate was between 89 and $112 \%$ of the maximum amount calculated from the composition of centrate samples (Figure 4). In contrast, the $\mathrm{Mg}^{2+}$ removal increased between 0 and $100 \mathrm{rpm}$ but later decreased as the stirring speeds increased, being slightly higher than the maximum that could be achieved by struvite precipitation (Figure 4). In this case, high $\mathrm{Mg}^{2+}$ removals at different speeds may be due to the precipitation of other $\mathrm{Mg}$ precipitates, such as $\mathrm{Mg}(\mathrm{OH})_{2}$ since the excess mass of external magnesium source can rapidly react with $\mathrm{OH}^{-}$ions in the solutions to produce these amorphous products [25].

The $\mathrm{Ca}^{2+}, \mathrm{Mg}^{2+}$ and $\mathrm{N}$ removal from the soluble phase was between 2.73 and $4.55 \mathrm{mmol} \mathrm{Ca}{ }^{2+}$, between 11.0 and

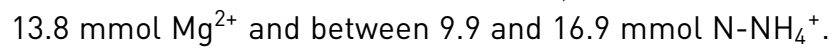
The $\mathrm{Ca}^{2+}$ removal may be due to the formation of calcium 

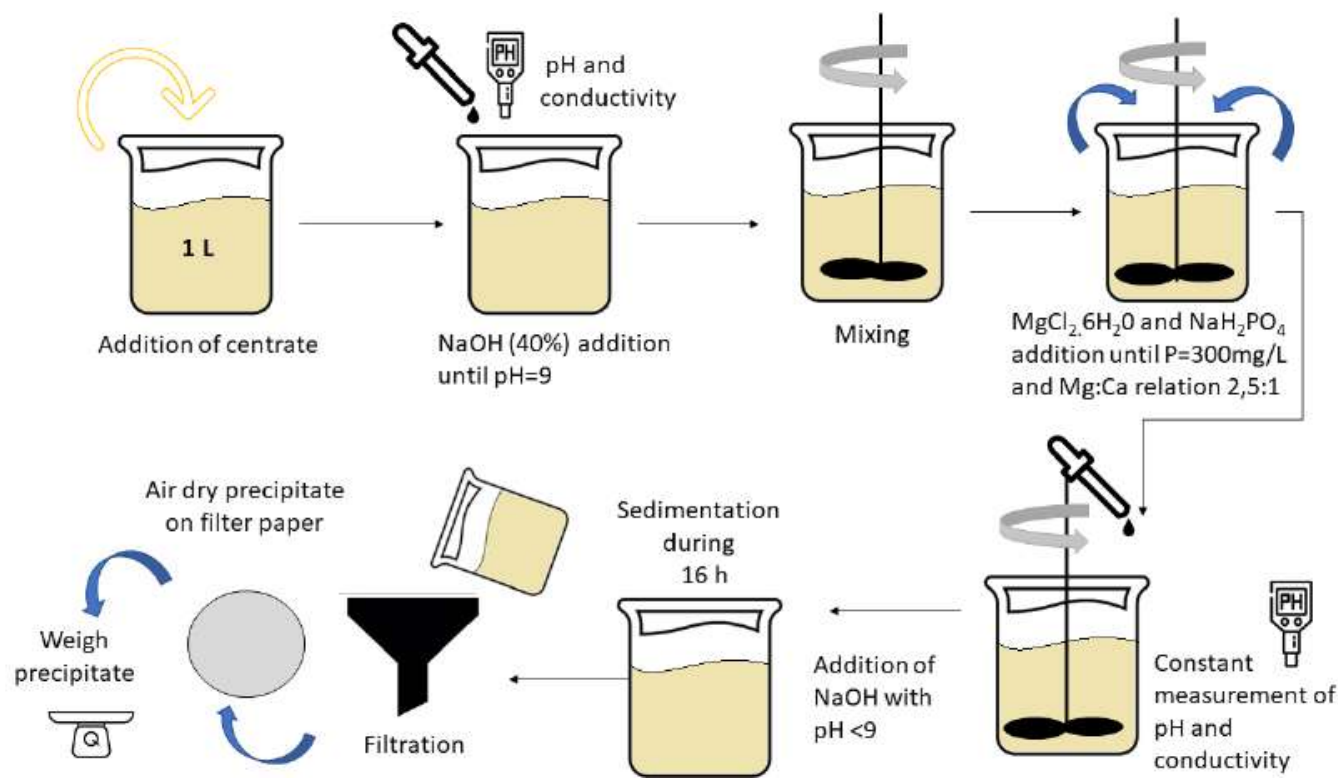

Figure 3 Experimental procedure for struvite precipitation

Table 2 Removal efficiencies (\%), struvite similarity score XRD (\%) and SEM-EDX results

\begin{tabular}{lllllllllll}
\hline $\begin{array}{l}\text { Stirring } \\
\text { Speed }\end{array}$ & $\begin{array}{l}\text { Velocity } \\
\text { gradient }\end{array}$ & \multicolumn{2}{l}{ Removal Efficiency (\%)* } & mass of crystals & XRD & \multicolumn{4}{c}{$\begin{array}{l}\text { SEM-EDX (\%) } \\
*\end{array}$} \\
\hline (rpm) & $\mathbf{s}^{-1}$ & $\mathbf{M g}$ & $\mathbf{C a}$ & $\mathbf{N}$ & $\mathbf{P}$ & $\mathbf{l g}$ & $\mathbf{S c o r e ( \% )}$ & $\mathbf{M g}$ & $\mathbf{P}$ & $\mathbf{C a}$ \\
\hline 0 & 0 & 81.8 & 69.7 & 16.8 & $>95$ & 2,1 & $97 \%$ & 14.9 & 18.5 & 0.6 \\
100 & 79 & 85.1 & 56.7 & 19.0 & $>95$ & 2,4 & $88 \%$ & 14.6 & 17.6 & 0.6 \\
200 & 188 & 81.8 & 69.7 & 23.9 & $>95$ & 2,5 & $90 \%$ & 13.8 & 16.4 & 1.6 \\
300 & 312 & 73.5 & 45.2 & 24.5 & $>95$ & 2,5 & $97 \%$ & 14.9 & 17.2 & 1.4 \\
400 & 447 & 67.6 & 63.6 & 28.5 & $>95$ & 2,6 & $87 \%$ & 14.3 & 15.4 & 1.8 \\
500 & 591 & 68.1 & 57.9 & 28.7 & $>95$ & 2,6 & $82 \%$ & 14.5 & 31.0 & 1.4 \\
\hline
\end{tabular}

${ }^{*}$ regarding the initial content in the soluble phase; ${ }^{* *}$ percentage of total atoms

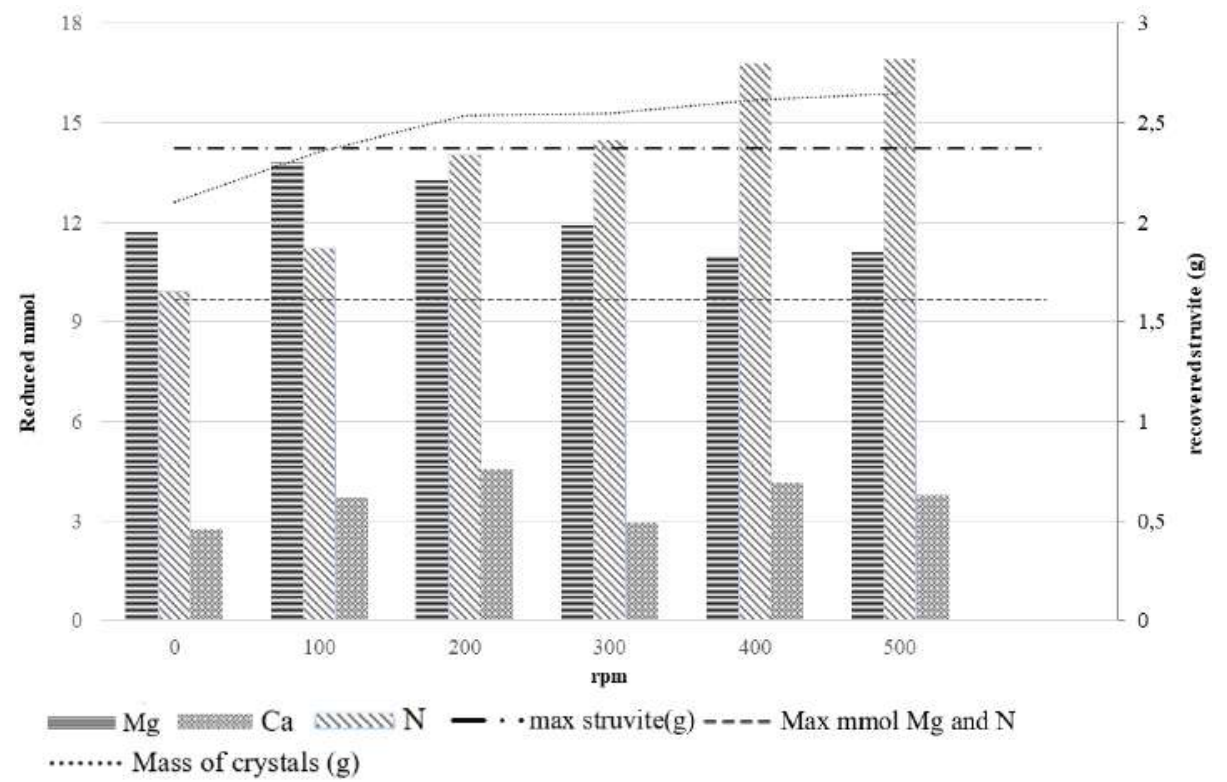

Figure 4 Reduced Mg, Ca and N (mmol) and recovered crystals depending on the stirring speed-velocity gradient 




Figure 5 XRD of precipitates at different stirred speeds and standard struvite (line in dark green)
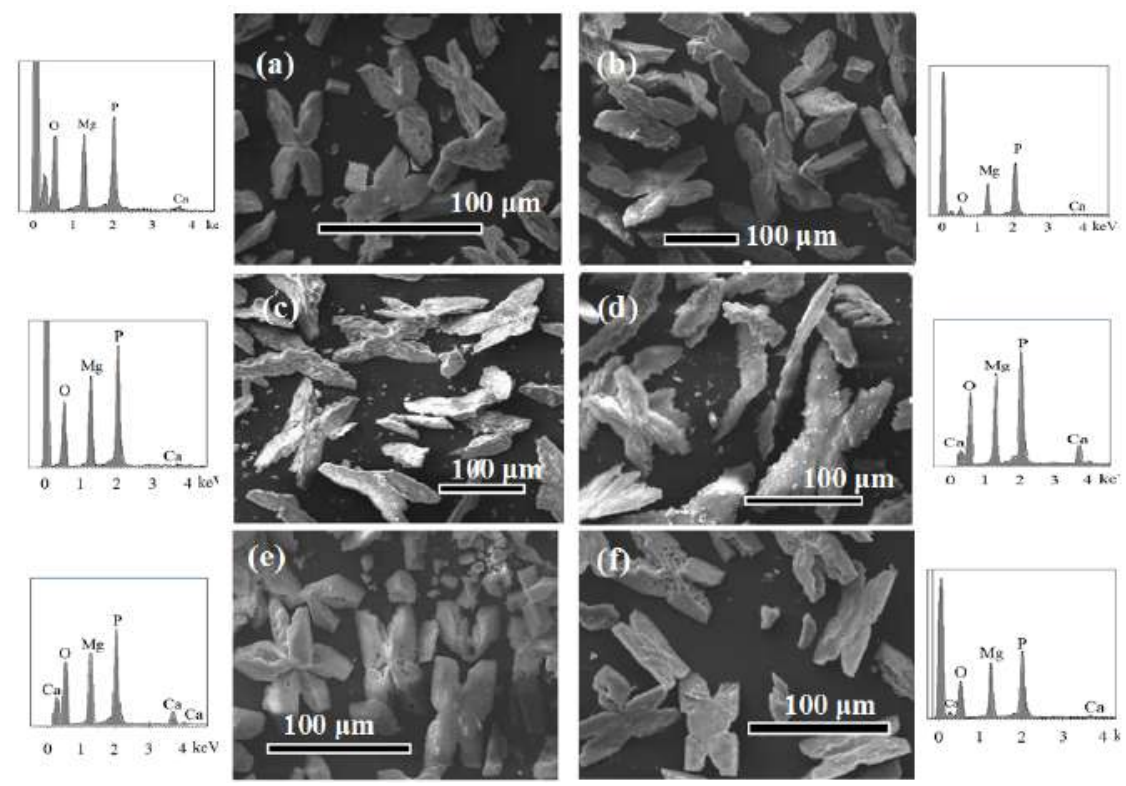

Figure 6 SEM images and EDS analysis of struvite crystals obtained working with different stirring speed: (a) 0 rpm, (b)100 rpm, (c) $200 \mathrm{rpm}$, (d) $300 \mathrm{rpm}$, (e) $400 \mathrm{rpm}$ and (f) $500 \mathrm{rpm}$

carbonates like calcite $\left(\mathrm{CaCO}_{3}\right)$ and monohydrocalcite $\left(\mathrm{CaCO}_{3} \cdot \mathrm{H}_{2} \mathrm{O}\right)$, more favoured in comparison with the formation of calcium phosphate $[29,36]$.

As reported in Figure 3, there was no direct relationship between the removal of $\mathrm{Mg}^{2+}$ and $\mathrm{Ca}^{2+}$. This is because the initial high magnesium content enhances the phosphate reaction with $\mathrm{Mg}^{2+}$ rather than $\mathrm{Ca}^{2+}$ [37], thereby reducing the interference due to the formation of $\mathrm{Mg}^{2+}$ and $\mathrm{Ca}^{2+}$ precipitates such as dolomite $\left(\mathrm{CaMg}\left(\mathrm{CO}_{3}\right)_{2}\right)$ and favours the formation of struvite.
High stoichiometric $\mathrm{NH}_{4}^{+}: \mathrm{PO}_{4}{ }^{3-}$ ratio $(\approx 4.7)$ favor the struvite precipitation [36]; however, the mass of crystals above the maximum expected for struvite at stirred speeds between $200 \mathrm{rpm}$ and $500 \mathrm{rpm}$ (Figure 3) may be due to the formation of other precipitates not detected in the XRD, since the agitation possibly favours other reactions.

Despite finding greater removal of $\mathrm{N}$ and $\mathrm{Mg}^{2+}$ than the maximum expected by struvite precipitation, it was found by X-ray diffraction that the main product obtained at all stirred speeds was struvite, finding similarities 




Figure 7 Distribution of particle size of struvite crystals at different stirring speeds

between 82 and $97 \%$ with the standard of struvite (Score in Table 2 and Figure 5). The SEM-EDX analyses confirmed the presence of $\mathrm{Mg}$ and $\mathrm{P}$ in the precipitates, with $\mathrm{a}$ minimum presence of $\mathrm{Ca}$ (Table 2 and Figure 6).

Although Pastor [33] concluded that the degree of agitation of the system can exert a considerable influence on the crystalline habit lexternal appearance of the crystals), similar crystal shapes were observed in this work - i.e., stars, X shapes and needles (Figure 6). The last shape, needles, are the most reported in by researchers, including Crutchik et al. [22].

The attained data in this work confirmed the strong influence of stirring speeds on particle size distribution. The largest mean particle size was found at $200 \mathrm{rpm}(128$ $\mu \mathrm{m}$; Figure 7) and the smallest size at $0 \mathrm{rpm}(55 \mu \mathrm{m})$. According to $t$-student tests, there were no statistically significant differences between the particle size of 100 and $200 \mathrm{rpm}$ ( $p$ >0.05); however, there were statistically significant differences between the particle size of 0 and $100 \mathrm{rpm}$, and 100 and $500 \mathrm{rpm}(p<0.05)$. Therefore, the largest particle sizes were between 100 and $200 \mathrm{rpm}$, which corresponds to a $G$ value between 79 and $188 \mathrm{~s}^{-1}$. According to Capdevielle et al.[30], high mixing rates have a negative impact on struvite crystal sizes due to struvite dissolution and crystal break, thus, although the mixing effect enhances mass transfer rates [25] and therefore the particle size, stirring speeds higher than $200 \mathrm{rpm}$ were detrimental to the struvite crystallisation process.

\section{Conclusions}

The struvite formation is affected by the stirring speed. The largest mean particle size of $128 \mu \mathrm{m}$ was obtained at $200 \mathrm{rpm}$ - i.e, equivalent to a $G$ of $188 \mathrm{~s}^{-1}$. The particle size of struvite crystals decreased with higher stirring speeds. Although the velocity gradient improves mass transfer rates of ions in the solution to support better crystal growth, high $G$ values beyond the optimal can revert this effect, reducing the size of crystals formed or disfavoring their growth rates.

The $P$ removal was not affected by stirring speeds, while the $\mathrm{N}$ removal increased with stirring speed achieving at $500 \mathrm{rpm}$ a removal of $7 \mathrm{mmol}$ more than the maximum possible by the sole formation of struvite. In this case, the agitation may favor the volatilization of $\mathrm{N}$ in the form of $\mathrm{NH}_{3}$ [38]. Although this did not affect the formation of struvite by the high contents of $\mathrm{N}^{-\mathrm{NH}_{4}}{ }^{+}$in the centrate, it implied an increased emission and a potentially higher environmental risk.

Although the removal of $\mathrm{Mg}$ appears to be influenced by the stirring speed, the precipitation of other salts was minimal compared to the struvite precipitation, according to XRD. Therefore, a stirring speed range between 100 and $200 \mathrm{rpm}$ (79 $\mathrm{s}^{-1}<\mathrm{G}<188 \mathrm{~s}^{-1}$ ) is recommended for struvite crystallisation with the benefit of producing large crystals, reducing energy consumption in stirring tanks, and reducing the volatilization of ammonia nitrogen. 


\section{Acknowledgments}

The authors would like to thank J. R. Navarro, L. Tey and E. Muñoz from IRTA, for their technical support and the La Llagosta WWTW for facilitating sample collection. C. González thanks Colciencias National Doctorates 647-2014 and Enlaza Mundos for the financial support for her PhD Internship. IRTA thanks the financial support of CERCA Program and the Consolidated Research Group TERRA (ref. 2017 SGR 1290), both from the Generalitat de Catalunya, as well as INIA support, from Gobierno de España, through the research project PIONER (ref. RTA2015-00093-00-00).

\section{References}

[1] A. Guadiea and et al., "Enhanced struvite recovery from wastewater using a novel cone-inserted fluidized bed reactor," J. Environ. Sci., vol. 26, no. 4, April 1 2014. [Online]. Available: https: //doi.org/10.1016/S1001-0742(13)60469-6

[2] Z. Ye and et al., "Phosphorus recovery from wastewater by struvite crystallization: Property of aggregates," J. Environ. Sci., vol. 26, no. 5, May 2014. [Online]. Available: https://doi.org/10.1016/ S1001-0742(13)60536-7

[3] J. D. Doyle and S. A. Parsons, “Struvite formation, control and recovery," Water Res., vol. 36, no. 16, September 2002. [Online]. Available: https://doi.org/10.1016/S0043-1354(02)00126-4

[4] N. Morales, M. A. Boehler, S. Buettner, C. Liebi, and H. Siegrist, "Recovery of $\mathrm{n}$ and $\mathrm{p}$ from urine by struvite precipitation followed by combined stripping with digester sludge liquid at full scale," water, vol. 5, no. 3, August 29 2013. [Online]. Available: https: //doi.org/10.3390/w5031262

[5] K. P. Fattah, "Assessing struvite formation potential at wastewater treatment plants," IJESD, vol. 3, no. 6, 2012. [Online]. Available: https://doi.org/10.7763/IJESD.2012.V3.284

[6] A. Uysal, Y. D. Yilmazel, and G. N. Demirer, “The determination of fertilizer quality of the formed struvite from effluent of a sewage sludge anaerobic digester," J. Hazard. Mater., vol. 181, no. 1-3, September 2010. [Online]. Available: https://doi.org/10.1016/j. jhazmat.2010.05.004

[7] R. W. Holloway, A. E. Childress, K. E. Dennett, and T. Y. Cath, "Forward osmosis for concentration of anaerobic digester centrate," Water Research, vol. 41, no. 17, September 2007. [Online]. Available: https://doi.org/10.1016/j.watres.2007.05.054

[8] E. M. Jordaan, "Development of an aerated struvite crystallization reactor for phosphorus removal and recovery from swine manure," M.S. thesis, University of Manitoba, Winnipeg, Canadá, 2011.

[9] P. Battistoni, A. D. Angelis, M. Prisciandaro, R. Boccadoro, and D. Bolzonella, "P removal from anaerobic supernatants by struvite crystallization: long term validation and process modellingr," Water Research, vol. 36, no. 8, April 2002. [Online]. Available: https://doi.org/10.1016/S0043-1354(01)00401-8

[10] A. Muhmood, J. Lu, R. Dong, and S. Wu, “Formation of struvite from agricultural wastewaters and its reuse on farmlands: Status and hindrances to closing the nutrient loop," J. Environ. Manage., vol. 230, January 15 2019. [Online]. Available: https://doi.org/10.1016/j. jenvman.2018.09.030

[11] B. Li and et al., “Phosphorous recovery through struvite crystallization: Challenges for future design," Sci. Total Environ., vol. 648, January 15 2019. [Online]. Available: https://doi.org/10.1016/j.scitotenv.2018.07.166

[12] K. S. L. Corre, E. Valsami, P. Hobbs, and S. A. Parsons, "Phosphorus recovery from wastewater by struvite crystallization: A review," Environ. Sci. Technol., vol. 39, no. 6, May 28 2009. [Online]. Available: https://doi.org/10.1080/10643380701640573
[13] M. M. Rahman and et al., "Production of slow release crystal fertilizer from wastewaters through struvite crystallization - a review," Arab. J. Chem., vol. 7, no. 1, January 2014. [Online]. Available: https://doi.org/10.1016/j.arabjc.2013.10.007

[14] X. Ye and et al., "A comprehensive understanding of saturation index and upflow velocity in a pilot-scale fluidized bed reactor for struvite recovery from swine wastewater," Powder Technol., vol. 295, July 2016. [Online]. Available: https://doi.org/10.1016/j.powtec.2016.03. 022

[15] P. Battistoni, R. Boccadoro, F. Fatone, and P. Pavan, “Auto-nucleation and crystal growth of struvite in a demonstrative fluidized bed reactor (fbr)," Environ. Technol., vol. 26, no. 9, May 11 2005. [Online]. Available: https://doi.org/10.1080/09593332608618486

[16] K. S. Le Corre and E. Valsami and P. Hobbs and B. Jefferson and S. A. Parsons, "Struvite crystallisation and recovery using a stainless steel structure as a seed material," Water Research, vol. 41, no. 11, June 2007. [Online]. Available: https://doi.org/10. 1016/j.watres.2007.03.002

[17] J. Wang, X. Ye, Z. Zhang, Y. Zhi, and S. Chen, “Selection of cost-effective magnesium sources for fluidized struvite crystallization," J. Environ. Sci., vol. 70, August 2018. [Online]. Available: https://doi.org/10.1016/j.jes.2017.11.029

[18] E. Tarragó, S. Puig, M. Ruscalleda, M. D. Balaguer, and J. Colprim, "Controlling struvite particles' size using the up-flow velocity," Chem. Eng. J., vol. 302, October 15 2016. [Online]. Available: https://doi.org/10.1016/j.cej.2016.06.036

[19] L. Pastor. (2006) Investigations on the recovery of phosphorus from wastewater by crystallization. [Dissertation.com]. [Online]. [Online]. Available: http://www.dissertation.com/m/books/1581123337

[20] M. Ronteltap, M. Maurer, R. Hausherr, and W. Gujer, “Struvite precipitation from urine - influencing factors on particle size," Water Res., vol. 44, no. 6, March 2010. [Online]. Available: https://doi.org/10.1016/j.watres.2009.12.015

[21] S. Dhakal, "A laboratory study of struvite precipitation for phosphorus removal from concentrated animal feeding operation wastewater," M.S. thesis, Missouri University of Science and Technology, Rolla, [USA], 2008.

[22] D. Crutchik, N. Morales, J. M. Garrido, and J. R. Vázquez, "Enhancement of struvite pellets crystallization in a full- scale plant using an industrial grade magnesium product," Water. Sci. Technol., vol. 75, no. 3, February 13 2017. [Online]. Available: https://doi.org/10.2166/wst.2016.527

[23] X. Liu and et al., "Influence of process parameters on phosphorus recovery by struvite formation from urine," Water Sci. Technol., vol. 68, no. 11, pp. 2434-2440, 2013.

[24] M. Cerrillo, J. Palatsi, J. Comas, J. Vicens, and A.Bonmatí, "Struvite precipitation as a technology to be integrated in a manure anaerobic digestion treatment plant - removal efficiency, crystal characterization and agricultural assessment," J. Chem. Technol. Biotechnol., vol. 90, no. 6, June 13 2015. [Online]. Available: https://doi.org/10.1002/jctb.4459

[25] D. Kim, J. Kim, R. Hong, and L. Sang, "Effect of mixing on spontaneous struvite precipitation from semiconductor wastewater," Bioresour. Technol., vol. 100, no. 1, January 2009. [Online]. Available: https://doi.org/10.1016/j.biortech.2008.05.024

[26] American Public Health Association and American Water Works Association and Water Environment Federation, Standard methods for the examination of water and wastewater, 20th ed. Washington, D.C: APHA-AWWA-WEF, 1998.

[27] The International Centre for Diffraction Data (ICDD). PDF-2. Accessed May. 28, 2019. [Online]. Available: http://www.icdd.com/ index.php/pdf-2/

[28] Image J, National institutes of Health, 2016.

[29] S. Rodrigues, “Precipitação de estruvita: recuperação de nitrogênio e fósforo utilizando fontes alternativas de reagentes," Ph.D. dissertation, Universidade Federal de Minas Gerais, Belo horizonte, Brazil, 2014.

[30] A. Capdevielle, E. Sýkorová, B. Biscans, F. Béline, and M. L. Daumer, "Optimization of struvite precipitation in synthetic biologically treated swine wastewater-determination of the optimal process 
parameters," J. Hazard. Mater., vol. 244-245, January 152013 [Online]. Available: https://doi.org/10.1016/j.jhazmat.2012.11.054

[31] N. Y. Acelas, E. Flórez, and D. López, “Phosphorus recovery through struvite precipitation from wastewater: effect of the competitive ions," Desalin. Water Treat, vol. 54, no. 9, March 27 2014. [Online]. Available: https://doi.org/10.1080/19443994.2014.902337

[32] X. D. Hao, C. C. Wang, L. Lan, and M. C. M. V. Loosdrecht, "Struvite formation, analytical methods and effects of ph and ca2+," Water Sci. Technol., vol. 58, no. 8, 2008. [Online]. Available: https://doi.org/10.2166/wst.2008.557

[33] L. Pastor, “Estudio de la precipitación y recuperación del fósforo presente en las aguas residuales en forma de estruvita (mgnh4po4.6h20)," Ph.D. dissertation, Departamento de Ingeniería Hidráulica y Medio Ambiente, Universidad Politécnica de Valencia, Valencia, España, 2008.

[34] D. A. Cornwell and M. M. Bishop, "Determining velocity gradients in laboratory and fullDscale systems," Journal (American Water Works Association), vol. 75, no. 9, September 01 1983. [Online]. Available: https://doi.org/10.1002/j.1551-8833.1983.tb05197.x
[35] M. I. H. Bhuiyan, D. S. Mavinic, and F. A. Koch, "Phosphorus recovery from wastewater through struvite formation in fluidized bed reactors: a sustainable approach." Water Sci. Technol., vol. 57, no. 2, 2008. [Online]. Available: https://doi.org/10.2166/wst.2008.002.

[36] D. Crutchik, S. Rodrigues, D. Ruddle, and J. M. Garrido, "Evaluation of a low-cost magnesium product for phosphorus recovery by struvite crystallization," J. Chem. Technol. Biotechnol., vol. 93, no. 4, April 2018. [Online]. Available: https://doi.org/10.1002/jctb.5453

[37] Y. Jaffer, T. A. Clark, P. Pearce, and S. A. Parsons, "Potential phosphorus recovery by struvite formation," Water Research, vol. 36, no. 7, April 2002. [Online]. Available: https://doi.org/10.1016/ S0043-1354(01)00391-8

[38] E. Ariyanto, H. M. Ang, and T. K. Sen, "The influence of various process parameters on dissolution kinetics and mechanism of struvite seed crystals," Journal of the Institution of Engineers (India): Series A, vol. 98, no. 3, September 2017. [Online]. Available: https://doi.org/10.1007/s40030-017-0212-4 